\title{
ANALISIS KEBIJAKAN INSENTIF DALAM RANGKA PERLINDUNGAN LAHAN PERTANIAN PANGAN BERKELANJUTAN DI INDONESIA
}

\author{
Eka N.A.M. Sihombing \\ Fakultas Hukum, Universitas Muhammadiyah Sumatera Utara, Indonesia \\ Email : ekahombing@umsu.ac.id
}

\author{
Andryan \\ Fakultas Hukum, Universitas Muhammadiyah Sumatera Utara, Indonesia \\ Email : andryan.umsu@gmail.com

\section{Mirsa Astuti} \\ Fakultas Hukum, Universitas Muhammadiyah Sumatera Utara, Indonesia \\ Email : mirsaastuti@umsu.ac.id
}

\begin{abstract}
Abstrak
Tujuan dari penelitian ini adalah untuk mengkaji kebijakan insentif yang berkelanjutan dalam perlindungan lahan pertanian pangan di masa mendatang. Untuk menahan laju konversi lahan pertanian menjadi lahan non-pertanian, Pemerintah bersama dengan Dewan Perwakilan Rakyat mengesahkan lahirnya Undang-Undang Nomor 41 Tahun 2009 tentang Perlindungan Lahan Pertanian Pangan Berkelanjutan. Undang-Undang ini diharapkan dapat menahan laju konversi lahan pertanian menjadi non-pertanian. Salah satu hal yang diatur dalam undang-undang tersebut adalah terkait dengan kebijakan pemberian insentif, akan tetapi kebijakan tersebutmasih berbasis lahan, sehingga insentif hanya diberikan kepada pemilik lahan pertanian yang tidak mengalihfungsikan lahan pertanian pangan. Di mana dengan perkembangan teknologi sekarang ini serta untuk menjaga ketahanan pangan, maka pengembangan varietas unggul pertanian tidak harus dikembangkan berbasis lahan. Oleh karena itu, untuk menjaga ketahanan pangan, diperlukan suatu upaya untuk mengembangkan kebijakan yang tidak hanya berbasis lahan. Metode yang digunakan dalam penelitian ini adalah metode penelitian hukum yuridis normatif dengan menggunakan pendekatan perundang-undangan (statute approach). Analisis data dilakukan dengan menggunakan metode kualitatif berdasarkan logika berpikir deduktif. Berdasarkan penelitian yang dilakukan diperoleh bahwa kebijakan pemberian insentif kepada petani masih berbasis luas lahan, di mana salah satu pertimbangan pemberian insentif adalah memiliki luas tanam paling sedikit 25 (dua puluh lima) hektar dan kebijakan pemberian insentif kepada petani dalam rangka perlindungan lahan pertanian dinilai kurang tepat, karena insentif yang diberikan masih berupa program reguler yang dilaksanakan oleh pemerintah.
\end{abstract}

Kata Kunci: Lahan; Pertanian Berkelanjutan; Insentif.

\section{Abstract}

The aim of this study is to examine sustainable incentive policies for the protection of agricultural food land in the future. To curb the rate of conversion of agricultural land to non-agricultural land, the Government together with the House of Representatives ratified the issuance of Law Number 41 of 2009 concerning the Protection of Sustainable Food Agricultural Land. This law is hoped to be able to hold back the rate of conversion of agricultural land to non-agricultural land. One of the things regulated in this law is related to the policy of providing incentives, but the policy is still land-based, so that incentives are only given to agricultural land owners who do not convert the land for food agriculture. Where with current technological developments and to maintain food security, the development of agricultural superior varieties does not have to be developed based on land. Therefore, to maintain food security, an effort is needed to develop policies 
that are not only land-based. The method used in this research is a normative juridical legal research method using a statutory approach. Data analysis was performed using qualitative methods based on deductive thinking logic. Based on the research conducted, it was found that the policy of providing incentives to farmers was still based on land area, where one of the considerations for providing incentives was to have a planting area of at least 25 (twenty five) hectares and the policy of providing incentives to farmers in the framework of protecting agricultural land was considered inappropriate. , because the incentives given are still in the form of a regular program implemented by the government.

Keywords: Land; Sustainable Agriculture; Incentive.

\section{A. PENDAHULUAN}

Kekayaan Negara Indonesia salah satunya dalam sektor pertanian, sebagian besar penduduknya memiliki sumber pendapatan dari sektor ini, contohnya seperti petani. Sebagai negara agraris yang masih memainkan peran dominan dalam bidang ekonomi dan dalam hal untuk menciptakan lapangan kerja. Menurut survei Angkatan Kerja Nasional, diperkirakan bahwa sekitar 38 (tiga puluh delapan) juta pekerja masih bertahan hidup di sektor pertanian. ${ }^{1}$

Sebagai penyedia lapangan kerja inilah peran sektor pertanian yang tetap tinggi dan belum ada penggantinya itu disebabkan karena sifat kegiatan sektor pertanian yang masih tradisional yaitu tidak membutuhkan keterampilan yang tinggi, sehingga sektor ini fleksibel dalam menyerap tenaga kerja. Selain itu, kegiatan pertanian juga memainkan peran di bidang sumber daya tahan yang melimpah. Terkait bercocok tanam, maka otomatis tidak jauh dari lahan. Tanah merupakan faktor utama dalam mengembangkan pertanian. Sifat lahan yang tidak bertambah namun kebutuhan atas lahan itu terus bertambah, sehingga jika tidak ada wujud pembangunan berkelanjutan, maka generasi mendatang akan sulit untuk memenuhi kebutuhan akan lahan itu.. ${ }^{2}$

Berkurangnya lahan pertanian ini terjadi karena maraknya alih fungsi lahan pertanian yang dipicu antara lain karena (1) faktor ekonomi; (2) faktor pemekaran daerah otonom; dan (3) kebijakan pangan seperti impor pangan. Selain faktor-faktor tersebut, erosi lahan pertanian yang disebabkan oleh aktivitas ekonomi manusia terutama permukiman, pembangunan infrastruktur seperti jalan, bendungan, dll, atau industri. Pembangunan masih menyebabkan banyak lahan pertanian dialihkan untuk non-pertanian. Pemerintah bersama DPR mengesahkan UndangUndang Nomor 41 Tahun 2009 tentang Perlindungan Lahan Pertanian Pangan Berkelanjutan. Undang-undang tersebut diharapkan dapat menurunkan laju konversi lahan pertanian menjadi non pertanian.

Salah satu peraturan pelaksana dari undang-undang tersebut diundangkanlah Peraturan Pemerintah Nomor 12 Tahun 2012 tentang Insentif Perlindungan Lahan Pertanian Pangan Berkelanjutan, di mana dalam Pasal 1 angka 3 menyatakan bahwa yang berintikan bahwa hukum menciptakan adanya dorongan diberikan untuk pihak yang memelihara (petani) yang tidak berpindah-pindah lahan pertanian yang berkelanjutan. Hal ini karena tanah pertanian produktif adalah aset prioritas berdasarkan dua (2) hal, yaitu jumlah biaya investasi yang terjadi dalam bentuk irigasi, infrastruktur, cetak lahan baru dan panjang waktu yang diperlukan untuk membuat lahan baru untuk membentuk bidang produksi dengan tingkat produktivitas sawah yang tinggi. ${ }^{3}$

${ }^{1}$ Dian Ayu Wulandari and Amni Zarkasyi Rahman, (2017) "Implementasi Kebijakan Perlindungan Lahan Pertanian Pangan Berkelanjutan (LP2B) Di Kabupaten Tegal (Studi Implementasi Peraturan Daerah Kabupaten Tegal Nomor 10 Tahun 2012 Tentang Rencana Tata Ruang Wilayah Kabupaten Tegal Tahun 2012-2032)," Journal of Public and Management Review 6, no. 2. Hlm 1

${ }^{2}$ Badan Pembinaan Hukum Nasional.(2017). Analisis Dan Evaluasi Hukum Dalam Rangka Perlindungan Lahan Pertanian Pangan Berkelanjutan. Jakarta, hlm 1

${ }^{3}$ Alimansyah and Dkk, "Analisis Implementasi PP No. 12 Tahun 2012 Tentang Insentif Perlindungan Lahan Pertanian

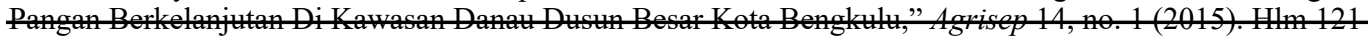


Tujuan pemberian insentif bagi petani yang melaksanakan perlindungan lahan pertanian secara konsisten dalam rangka ketahanan pangan berkelanjutan berdasarkan ketentuan PP Nomor 12 Tahun 2012 pada dasarnya ialah untuk meningkatkan upaya untuk mengontrol, mempromosikan lahan pertanian yang berkelanjutan dan berkelanjutan dan meningkatkan kemitraan di antara semua stakeholders dalam konteks penggunaannya, berkelanjutannya lahan pertanian dengan perencanaan spasial. Insentif ditawarkan untuk mengembangkan infrastruktur pertanian, pendanaan penelitian dan pengembangan bibit premium dan varietas, akses mudah untuk informasi dan teknologi, menyediakan produksi dan fasilitas infrastruktur, memastikan hak lahan pertanian pada lahan pertanian yang berkelanjutan, dan / atau penghargaan untuk petani berprestasi tinggi.

Kebijakan pemberian insentif tersebut pada dasarnya suatu hal yang positifakan tetapi apabila diperhatikan bahwa kebijakan tersebut masih berbasis lahan, ${ }^{4}$ sehingga insentif hanya diberikan kepada pemilik lahan pertanian yang tidak mengalihfungsikan lahan pertanian pangan. Hal ini tentu bertentangan dengan jenis insentif yang diberikan yaitu berupa pembiayaan benih dan varietas unggul. Di mana dengan perkembangan teknologi sekarang ini serta untuk menjaga ketahanan pangan, maka pengembangan varietas unggul pertanian tidak harus dikembangkan berbasis lahan. Oleh karena itu untuk mewujudkan ketahanan pangan, diperlukan suatu upaya untuk mengembangkan kebijakan yang tidak hanya berbasis lahan. Berdasarkan latar belakang di atas, maka permasalahan yang akan diurai lebih lanjut adalah bagaimana kebijakan insentif yang berkelanjutan dalam perlindungan lahan pertanian pangan di masa mendatang?

\section{B. METODE PENELITIAN}

Metode yang digunakan dalam penelitian ini adalah metode penelitian hukum normatif. Penelitian normatif harus menggunakan pendekatan hukum (pendekatan undang-undang), yang akan dianalisis dengan aturan hukum.. ${ }^{5}$ Menggunakan istilah Dworkin, penelitian jenis ini juga disebut penelitian doktrinal, penelitian yang menganalisis hukum, apakah itu ditulis dalam sebuah buku (hukum seperti yang tertulis dalam buku). Dalam penelitian ini, studi pustaka dan dokumen digunakan sebagai bahan prioritas sementara data lapangan yang diperoleh melalui wawancara akan digunakan sebagai pendukung atau komentar data dalam hal klarifikasi data.

Metode pengumpulan data yang digunakan dalam penelitian ini adalah studi pustaka dengan menelusuri pustaka-pustaka buku yang ada di kota Medan.

Data analisis adalah proses pengorganisasian dan memilah data ke dalam jenis kategori dasar dan unit deskripsi, sehingga ditemukan topik dan hipotesis dapat dirumuskan, seperti yang diusulkan oleh data. ${ }^{6}$ Untuk membangun hipotesis, sehingga teori tidak secara tidak langsung digunakan sebagai pisau analisis dalam sambungan dengan aplikasi yang benar prinsip konten dalam pembentukan peraturan regional. Hal ini diharapkan bahwa kegiatan ini akan difasilitasi dalam analisis dan interpretasi masalah yang ditimbulkan dan kemudian menarik kesimpulan. Analisa kualitatif dilakukan pada model hubungan dinamis antara teori, konsep dan data yang konstan atau modifikasi teori dan konsep berdasarkan data yang dikumpulkan. Hal ini dilakukan bersamaan dengan berbagai data yang memiliki sifat dasar yang berbeda satu sama lain.

\footnotetext{
${ }^{4}$ Jikapun ada yang berbasis holtikultura, kebijakan insentif tersebut hanya diberikan kepada pelaku usaha untuk memproduksi sarana hortikultura yang belum dapat diproduksi didalam negeri. Lebih lanjut lihat ketentuan Pasal 34 UU Nomor 2010 tentang Holtikultura.

${ }^{5}$ Joenaidi Efendi and Johnny Ibrahim. (2018). Metode Penelitian Hukum (Normatif Dan Empiris) Jakarta: PrenadaMedia. hlm. 132

${ }^{6}$ Lexy J Moleong. (1983). Metode Penelitian Kualitatif . Bandung: Remaja Rosdakarya. hlm. 280
} 


\section{PEMBAHASAN}

\section{Pembangunan Pertanian Berkelanjutan}

Pembangunan yang berkelanjutan berorientasi untuk memenuhi kebutuhan generasi sekarang tanpa mengorbankan kemampuan generasi masa depan. Untuk mencapai tujuan pembangunan berkelanjutan, ada empat prinsip-prinsip yang harus dipenuhi, yaitu, memenuhi kebutuhan dasar, mempertahankan integritas lingkungan, dan keadilan sosial. Sehingga, menurut Hadi hal itu sangat senada jika kita mengadopsi definisi pembangunan yang berkelanjutan dari Komite Lingkungan dan Pembangunan Yang Berkelanjutan (Word Commision on Enviroment and Development). ${ }^{7}$

Organisasi Pangan Dunia mendefinisikan pertanian yang berkelanjutan sebagai wujud mengelola dan melestarikan basis sumber daya alam, membawa perubahan teknologi dan institusional untuk memastikan bahwa kebutuhan manusia terpenuhi dan kebutuhan generasi masa depan tidak terbengkalai. Pembangunan pertanian berkelanjutan, perlindungan air, lahan, tanaman dan sumber daya genetik hewan, tidak merugikan lingkungan, secara teknis efisien, pangan, patut secara sosial dan ekonomi. ${ }^{8}$

Segitiga dari konsep pembangunan berkelanjutan, aktivitas pembangunan berkelanjutan (termasuk agribisnis dan pertanian) dinyatakan berkelanjutan, jika aktivitas tersebut bernilai ekonomis, lingkungan yang berkelanjutan secara sosial. Peningkatan ekonomi berarti bahwa setiap aktivitas itu harus berorientasi pada pertumbuhan dan peningkatan ekonomi, menggunakan sumber daya dan investasi secara efisien. Ketahanan Lingkungan berarti bahwa kegiatan ini harus mampu mempertahankan integritas ekosistem, mempertahankan ketahanan lingkungan dan melestarikan sumber daya alam termasuk keanekaragaman hayati. Pada saat yang sama, ketahanan sosial membutuhkan aktivitas pembangunan yang sempurna untuk mencapai hasil pembangunan yang adil. Meskipun ada banyak definisi pembangunan yang berkelanjutan, termasuk pertanian yang berkelanjutan, banyak diterima bahwa didasarkan pada tiga pilar: ekonomi, sosial dan lingkungan. Dengan kata lain, konsep pertanian yang berkelanjutan berorientasi terhadap tiga dimensi keberlanjutan dari lembaga-lembaga ekonomi yang profit oriented (berorientasi pada keuntungan), keberlanjutan kehidupan sosial manusia, dan keberlanjutan lingkungan alami.. ${ }^{9}$

Dimensi ekonomi berhubungan pendapatan yang dihasilkan dengan melestarikan aset yang membentuk dasar untuk memperoleh pendapatan. Standarisasi pertama dari dimensi ekonomi ini adalah tingkat ketangkasan, daya saing, volume dan ekonomi yang berada pada posisi stabil untuk cadangan ekonomi bagi generasi mendatang. ${ }^{10}$

Dimensi sosial, mengarah pada masyarakat, berhubungan dengan suksesi dan sejahteranya masyarakat dalam masyarakat yang teratur dan mampu melakukan preventif terhadap suatu konflik sosial, pelestarian budaya, keanekaragaman dan ibukota sosial dan budaya, termasuk perlindungan etnis minoritas. Untuk alasan ini, kemiskinan aeviation, distribusi yang adil bisnis dan peluang penghasilan, socio-political partisipasi, dan stabilitas sosial dan budaya adalah indikator penting yang harus diperhatikan ketika mengimplementasikan pembangunan itu. ${ }^{11}$

\footnotetext{
${ }^{7}$ SP Hadi. (2005). Dimensi Lingkungan Perencanaan Pembangunan, Yogyakarta: Gajah Mada University. hlm. 143

${ }^{8}$ Food Agriculture Organization (FAO), (1989) "Sustainable Development and Natural Resources Management," in FOOD AND AGRICULTURE ORGANIZATION OF THE UNITED NATIONS Twenty-Fifth Conference (Rome: Food and Agriculture Organization,. Paper C 89/2 Simp 2

${ }^{9}$ Rudy S Rivai and Iwan. S Anugrah, (2011) “Konsep Dan Implementasi Pembangunan Pertanian Berkelanjutan Di Indonesia," Forum Penelitian Agro Ekonomi 29, No. 1. hlm 15-16

${ }^{10}$ Ibid., hlm 16

${ }^{11}$ Ibid.
} 
Dimensi alam, untuk kestabilan ekosistem alam, pelestarian keanekaragaman hayati dan ketahanan biologis, tanah dan sumber air serta iklim pertanian, serta kesehatan lingkungan dan kenyamanan. Fokus pada mempertahankan kelentasan dan dinamika ekosistem untuk beradaptasi untuk berubah, tidak mempertahankan model statis tidak mungkin untuk dicapai. Tiga dimensi ini mempengaruhi satu sama lain sehingga ketiganya harus dilihat dengan cara yang seimbang (balance). ${ }^{12}$

Stabilnya sistem sosial, lingkungan, dan sumber daya adalah dasar dari aktivitas ekonomi, sedangkan kesejahteraan ekonomi adalah sebuah prasyarat untuk mempertahankan stabilitas sosial dan budaya serta mempertahankannya. Konsep Brundtland. Pertama, penting untuk memperhatikan batasan Sumber Daya Alam dan lingkungan pada pengembangan dan pola konsumsi. Hall menyatakan bahwa asumsi kelangsungan hidup didasarkan pada setidaknya tiga aksioma fundamental; (1) implementasi saat ini dan masa depan yang memberikan nilai jangka panjang positif; (2) mengakui bahwa aset lingkungan berkontribusi terhadap kesejahteraan ekonomi; dan (3) pengetahuan mengenai kendala yang disebabkan oleh efek-efek pada aset lingkungan. ${ }^{13}$

\section{Ketahanan Pangan}

Definisi ketahanan pangan diformulasikan dalam UU Pangan.ada diferensiasi pengertian antara yang berlaku di Indonesia dan di komunitas internasional, namun hakikatnya, para legislator telah membatasi ketahanan pangan yang merangkum poin penting sebagai berikut: (1) kebutuhan makanan di level individu; (2) kriteria untuk kebutuhan pangan termasuk berbagai hal,: Dalam hal kuantitas; dengan kualitas yang baik, dapat digunakan, ketersediaan dari berbagai jenis makanan dan makanan yang cukup; dalam hal makanan dalam batas-batas spiritual, pangan tidak boleh dilontarkan oleh hukum agama, kepercayaan, kepercayaan, kepercayaan dan budaya masyarakat; batas-batas makanan yang terjangkau, keadilan, kekurangan pangan, dan keperluan hidup, dengan harga yang cukup: (3) pangan yang sehat, serta yang terpenting berkelanjutan tentunya. ${ }^{14}$

Konsep ketahanan pangan lebih luas dari konsep swasembada dalam pangan, yang berfokus pada aspek fisik dari pembuatan pangan. Beberapa ahli setuju bahwa ketahanan pangan memiliki setidaknya dua komponen utama, ketersediaan pangan dan akses publik untuk bahan makanan ( foodstuffs) ini. Salah satu elemen di atas tidak bertemu, sehingga tidak dapat dikatakan bahwa negara memiliki kecukupan atas ketahanan pangan. ${ }^{15}$

Deskripsi ketahanan pangan, yang berisi unsur-unsur ketersediaan pangan dan akses yang lebih luas ke masyarakat, harus diterjemahkan ke dalam ketersediaan fisik dari kuantitas, kualitas dan keberlanjutan untuk memenuhi orang-orang; kebutuhan konsumen, sementara aksesibilitas masyarakat dapat dibagi menjadi distribusi, dan ketahanan pangan. distribusi memainkan peran dalam memfasilitasi orang \& akses ke pangan dengan cepat dan dengan biaya yang memadai. konsumsi terkait dengan keanekaragaman dan kualitas pangan dikonsumsi tidak hanya memuaskan tetapi juga kualitas yang baik. Ketahanan termasuk dua aspek, keselamatan dinamakan dari sisi fisik, yang tidak terkontaminasi oleh zat berbahaya, baik kimia, serta polutan aman lainnya, yaitu halal. ${ }^{16}$

${ }^{12}$ Ibid., hlm 16-17

${ }^{13} \mathrm{Ibid}$.

${ }^{14}$ Ahmad Suryana.(2014). "Menuju Ketahanan Pangan Indonesia Berkelanjutan 2025: Tantangan Dan Penanganannya," Forum Penelitian Agro Ekonomi 32, no. 2. hlm. 124

${ }^{15}$ Rossi Prabowo. (2010). "Kebijakan Pemerintah Dalam Mewujudkan Ketahanan Pangan Di Indonesia," Mediagro 6, no. 2. hlm 66

${ }^{16}$ Ibid. 
Sistem ketahanan pangan terdiri dari tiga subsistem, yaitu ketersediaan, keterjangkauan, dan pemanfaatan pangan. Berbagai parameter dapat dipakai untuk mengukur kinerja ketahanan pangan, antara lain parameter gizi pada anak usia di bawah lima tahun atau balita (pemanfaatan), proporsi penduduk miskin, pencapaian skor Pola Pangan Harapan (PPH), pencapaian sasaran swasembada lima komoditas pangan penting, konsumsi energi dan protein per kapita (keterjangkauan), ketersediaan energi dan protein per kapita (ketersediaan). ${ }^{17}$

\section{Kebijakan Pertanian Pangan Berkelanjutan}

Kebijakan pertanian pangan berkelanjutan di Indonesia diatur dalam UU No. 41 Tahun 2009 menjabarkan tujuan lahan pangan yang berkelanjutan dilindungi pada intinya ialah sebagai berikut melindungi daerah dan tanah untuk Pangan pertanian yang berkelanjutan, memastikan ketersediaan lahan pangan dengan cara yang berkelanjutan, mendapatkan kemerdekaan pangan, ketahanan dan kedaulatan, perlindungan lahan pangan pertanian milik petani, untuk meningkatkan kemakmuran dan kesejahteraan petani dan masyarakat, meningkatkan perlindungan dan pemberdayaan petani, meningkatkan pekerjaan untuk kehidupan yang layak, menjaga keseimbangan ekologi, mencapai revitalisasi pertanian, lingkup perlindungan pangan yang berkelanjutan. Sedangkan ruang lingkupnya mencakup perencanaan dan penetapan, pengembangan (development), penelitian (research), pemanfaatan, pembinaan, kontrol, pengendalian, sistem informasi, melindungi dan memberdayakan petani, finance (keuangan).

Kebijakan yang dibuat dalam Undang-Undang Nomor 41 Tahun 2009 tentang Perlindungan Lahan Pertanian Pangan Berkelanjutan pada tahap implementasi dapat diuraikan pada intinya ialah dilakukan secara sepihak oleh pemerintah, tidak berdasarkan pendapat atau saran dari masyarakat terkait perencanaan dan penentuan LP2B di RTRW. Alasannya adalah bahwa mereka tidak memiliki cukup informasi untuk mencampur masyarakat LP2B, daerah yang telah menciptakan regulasi Bupati di LP2B, yaitu tab Regency, dan daerah Garutanan dan Maros saat ini menyusun Peraturan ini, ada 6 daerah yang telah dilakukan penelitian LP2B terkait dengan pendanaan APBD dimana mereka menggunakan hasil pencarian untuk mempersiapkan tata letak LP2B, the development, gunakan dan aspek bimbingan belum dilaksanakan sampai sanksi aspek sebab daerah menitikberatkannya pada proses planning (perencanaan) dan identifikasi dari LP2B, daerah tertentu tanah LP2B di daerah zona dan yang lebih kecil masih mencapai tingkat sub-zona karena lebih aman jika perubahan di tanah terjadi di masa depan, yang muncul dalam koneksi dengan LP2B adalah kurangnya sosialisasi untuk LP2B di tingkat pusat dan lokal, dan ketidakmampuan organisasi untuk mentransfer fungsi kendali. ${ }^{18}$

Salah satu kebijakan yang dilaksanakan berdasarkan Undang-Undang Nomor 41 Tahun 2009 tentang Perlindungan Lahan Pangan Berkelanjutan adalah pemberian insentif. Di mana, insentif yang diberikan pada intinya berupa pembebasan pajak, pembangunan infrastruktur pertanian, pembiayaan penelitian dan pengembangan bibit baik varietas, akses mudah ke informasi dan teknologi, penyediaan fasilitas produksi pertanian dan infrastruktur, pastikan issuance sertifikat tanah untuk pertanian pangan melalui intermittent dan pendaftaran tanah biasa; dan / atau, penghargaan untuk petani yang luar biasa berprestasi.

Namun pemberian insentif berdasarkan ketentuan Pasal 40 Undang-Undang Nomor 41 Tahun 2009 tentang Perlindungan Lahan Pertanian Pangan Berkelanjutan diberikan dengan mempertimbangkan yang pada intinya sebagai berikut kolektivitas usaha pertanian, irigasi,

\footnotetext{
${ }^{17}$ Suryana, "Menuju Ketahanan Pangan Indonesia Berkelanjutan 2025: Tantangan Dan Penanganannya." Hlm. 125-126

${ }^{18}$ Direktorat Pangan dan Pertanian Kementerian Perencanaan Pembangunan Nasional Bappenas, (2015) Evaluasi Implementasi Kebijakan Lahan Pertanian Pangan Berkelanjutan (LP2B) (Jakarta: Direktorat Pangan dan Pertanian Kementerian Perencanaan Pembangunan Nasional/Badan Perencanaan Pembangunan Nasional). Hlm viii
} 
jenis lahan pertanian pangan berkelanjutan, tingkat fragmentasi lahan, lokasi, luas tanam, praktik usaha tani ramah lingkungan, produktivitas usaha tani, dan kesuburan tanah;

Lebih lanjut dalam Peraturan Pemerintah Nomor 12 Tahun 2012 tentang Insentif Perlindungan Lahan Pertanian Pangan Berkelanjutan disebutkan bahwa luas tanam paling sedikit 25 (dua puluh lima) hektar dalam satu hamparan. Selain itu, program pemberian insentif dalam Undang-Undang Nomor 41 Tahun 2009 tentang Perlindungan Lahan Pertanian Pangan Berkelanjutan hampir seluruhnya merupakan progam reguler dan tidak terdapat perbedaan antara petani LP2B dan bukan LP2B, sehingga dalam implementasi kurang berhasil. ${ }^{19}$

\section{Analisis Kebijakan Insentif dalam rangka Perlindungan Pertanian Pangan Berkelanjutan}

Wibowo ${ }^{20}$ Proses analisis kebijakan adalah serangkaian kegiatan intelektual dilakukan dalam kerangka kerja proses aktivitas politik. Tampilkan aktivitas politik dalam serangkaian kegiatan, mengadopsi kegiatan, menerapkan kebijakan, dan Evaluasi Kebijakan. Pada saat yang sama, aktivitas formulasi masalah, penyitaan, rekomendasi kebijakan, pemantauan dan evaluasi kebijakan adalah kegiatan yang lebih bersifat intelektual. ${ }^{21}$

Pemerintah telah banyak melakukan segala daya dan upaya untuk kemajuan sektor pertanian, sebab terdapat banyak faktor yang menjadikan pertanian sebagai salah satu bidang yang diutamakan untuk pembangunan khususnya dalam hal pembangunan berkelanjutan, karena faktor Indonesia yang juga merupakan negara berkembang sehingga menjadi sasaran bagi pembeli dari komunitas pertanian sehingga perlu dioptimalkan, sebab untuk negara-negara industri yang bukan negara agraris tidak memiliki potensi yang baik dalam hal sektor pertanian ini. Pembangunan ini juga bertujuan untuk mengefisiensikan biaya produksi pertanian dan juga menjadi jawaban atas kebutuhan bahan baku yang dibutuhkan oleh industri.

Transformasi model pertanian yang mengacu pada pembangunan pertanian inklusif adalah fokus utama untuk dikembangkan sebagai tujuan dari model pertanian harus memastikan independen dan berkelanjutan pangan dalam keluarga dan juga dalam negara. Untuk mencapai tujuan ini, ada banyak pendapat profesional bahwa negara harus mengambil sehubungan dengan model yang sama ini. Model pembangunan pertanian harus diubah dari sebuah terpusat ke pendekatan desentralisasi, dari komoditas ke sumber daya, dari pendekatan pertanian untuk meningkatkan kesejahteraan masyarakat pedesaan, dari subsistensi-skala komersial, dari kerjaintensif-untuk barang, dari barang bawaan ke nilai-nilai tambah. Untuk mendorong gelombang dan dari pemerintah dengan dominasi lebih besar keterlibatan sektor swasta.

Ada beberapa kriteria untuk mewujudkan pertanian berbudaya industri yaitu Pengetahuan adalah dasar utama untuk membuat keputusan (tidak hanya intuisi) sehingga kebutuhan untuk mengembangkan dan kualitas informasi yang lebih tinggi, kemajuan teknologi adalah alat utama yang menggunakan sumber daya, mekanisme pasar adalah alat utama dalam efisiensi dan produktivitas perdagangan dalam barang-barang dan layanan jasa, basis utama dalam alokasi sumber daya, sehingga menyimpan biaya manajemen sumber daya, kualitas dan teknisi, orientasi dan objektivitas, profesionalisme yang luar biasa, harus mengubah ketergantungan pada alam, sehingga setiap produk selalu memenuhi kebutuhan yang dihasilkan oleh pasar. ${ }^{22}$

\footnotetext{
${ }^{19}$ Badan Pembinaan Hukum Nasional, Analisis Dan Evaluasi Hukum Dalam Rangka Perlindungan Lahan Pertanian Pangan Berkelanjutan. hlm 85

${ }^{20}$ Willy Wibowo. (2020). "Hubungan Peneliti Dan Analis Kebijakan Dalam Pembuatan Rekomendasi Kebijakan Pada Badan Penelitian Dan Pengembangan Hukum Dan HAM," Jurnal Ilmiah Kebijakan Hukum 14, no. 1.hlm 81

${ }^{21}$ Andryan.(2019). Hukum Kebijakan Publik. Medan: Pustaka Prima. hlm 11-12

${ }^{22}$ Mahmuddin. (2013). "Paradigma Pembangunan Pertanian: Pertanian Berkelanjutan Berbasis Petani Dalam Perspektif Sosiologis," Jurnal Sosiologi Universitas Syiah Kuala 3, no. 3. hlm 68-69
} 
Ada beberapa kriteria untuk mencapai industri pertanian ialah untuk mencapai visi pembangunan pertanian sebagai modern, fleksibel dan efisien, harus didasarkan pada empat hal mengoptimalkan sumber daya pertanian dan mempertahankan keberlanjutan lingkungan. Pertanian sumber daya termasuk tanah, air dan air pada umumnya, laut, plasma genetik, sumber daya genetik, dan sumber daya energi. Manajemen sumber daya ini harus memenuhi prinsipprinsip ekonomi, prinsip efisiensi dan menunjukkan kebutuhan pasar, membuat diversifikasi komprehensif dimensi vertikal dan horizontal. Kunci keberhasilan pengembangan pertanian adalah penggunaan teknologi spesifik Situs, ketersediaan infrastruktur untuk pengembangan zona dan kehadiran lembaga pendukung yang sesuai. Termasuk informasi pasar dan standardisasi produk. Diversifikasi tidak hanya dalam aktivitas produksi, tetapi juga dalam eksploitasi dan pemasaran produk pertanian. Menerapkan teknik canggih yang spesifik untuk situs. Kata kunci dalam kasus ini adalah kata lanjutan dan terlokalisasi, mempertimbangkan bahwa sumber daya pembangunan pertanian yang tersedia sangat beragam. Dengan aplikasi teknologi maju disesuaikan dengan kondisi lokal tertentu, upaya dapat dimaksimalkan untuk meningkatkan efisiensi pertanian memungkinkan. ${ }^{23}$

Untuk mencapai visi pembangunan pertanian yang modern tentunya pemberian insentif tetap perlu dipertahankan. Akan tetapi, diperlukan pemberian insentif yang memang memberikan nilai lebih bagi petani yang memperoleh insentif. Misalnya dengan memberikan biaya untuk petani yang berhasil mengembangkan produksi tanaman pertanian yang sangat dibutuhkan oleh masyarakat setempat. Juga dengan memberikan bantuan benih-benih unggul yang dihasilkan dari lembaga-lembaga pemerintahan yang mempunyai tugas dalam melakukan penelitian pertanian.

Dengan demikian, maka pemberian insentif dengan berbasis luas tanam juga secara otomatis tidak harus diterapkan lagi secara penuh. Di mana, pemberian insentif diberikan bukan hanya kepada petani yang mempunyai dan mempertahankan lahan pertaniannya mulai dari 1 (satu) hektare, tetapi juga kepada petani yang berhasil mengembangkan metode atau teknologi di bidang pengembangan pertanian walaupun lahan yang dimilikinya tidak mencapai 25 (dua puluh lima) hektar.

Selain itu, kebijakan pemberian insentif ini sudah seharusnya juga memperhatikan latar belakang petani yang bersangkutan, agar pemberian insentif tersebut menjadi tepat sasaran. Di mana kepada petani yang kemampuannya sudah memadai, maka dipertimbangkan pemberian insentifnya tidak berbentuk bantuan langsung, tetapi dapat berupa pemberian keringan-keringan seperti keringan pajak bumi dan bangunan, dan sebagainya. Akan tetapi, kepada petani yang memang kemampuannya belum memadai, akan lebih baik jika insentif yang diberikan adalah bantuan langsung seperti bantuan bibit, pupuk, dan biaya-biaya lain yang diperlukan.

\section{KESIMPULAN}

Berdasarkan pembahasan di atas dapat disimpulkan bahwa kebijakan pemberian insentif kepada petani masih berbasis luas lahan, di mana salah satu pertimbangan pemberian insentif adalah memiliki luas tanam paling sedikit 25 (dua puluh lima) hektar, kebijakan pemberian insentif kepada petani yang sedemikian dinilai kurang tepat, karena insentif yang diberikan masih berupa program reguler yang dilaksanakan oleh pemerintah. Untuk mencapai tujuan perlindungan lahan pertanian pangan yaitu untuk ketahanan pangan, maka kebijakan pemberian insentif berbasis lahan sudah tidak sesuai lagi dengan perkembangan teknologi, oleh karena itu disarankan agar pemberian insentif tidak hanya kepada pemiliki lahan 25 (dua puluh lima) hektar saja, tetapi juga kepada semua petani yang memiliki lahan dan tetap mempertahankan lahan tersebut sebagai lahan

\footnotetext{
${ }^{23}$ Ibid., hlm 69-70
} 
pertanian, selain itu diperlukan bentuk insentif lain selain insentif yang sudah diatur dalam Undang-Undang Nomor 41 Tahun 2009 tentang Perlindungan Lahan Pertanian Pangan Berkelanjutan dengan mempertimbangkan kemampuan dari petani yang memiliki lahan.

\section{DAFTAR PUSTAKA}

\section{Buku:}

Andryan. (2019) Hukum Kebijakan Publik. Medan: Pustaka Prima.

Badan Pembinaan Hukum Nasional. (2017) Analisis Dan Evaluasi Hukum Dalam Rangka Perlindungan Lahan Pertanian Pangan Berkelanjutan. Jakarta.

Bappenas, Direktorat Pangan dan Pertanian Kementerian Perencanaan Pembangunan Nasional. (2015) Evaluasi Implementasi Kebijakan Lahan Pertanian Pangan Berkelanjutan (LP2B). Jakarta: Direktorat Pangan dan Pertanian Kementerian Perencanaan Pembangunan Nasional/Badan Perencanaan Pembangunan Nasional.

Efendi, Joenaidi, and Johnny Ibrahim (2018). Metode Penelitian Hukum (Normatif Dan Empiris). Jakarta: PrenadaMedia.

Hadi, SP. (2005) Dimensi Lingkungan Perencanaan Pembangunan. Yogyakarta: Gajah Mada University.

\section{Jurnal, Majalah, Prosiding :}

(FAO), Food Agriculture Organization (1989). "Sustainable Development and Natural Resources Management." In FOOD AND AGRICULTURE ORGANIZATION OF THE UNITED NATIONS Twenty-Fifth Conference. Rome: Food and Agriculture Organization.

Alimansyah, and Dkk. “(2015) Analisis Implementasi PP No. 12 Tahun 2012 Tentang Insentif Perlindungan Lahan Pertanian Pangan Berkelanjutan Di Kawasan Danau Dusun Besar Kota Bengkulu.” Agrisep 14, no. 1.

Mahmuddin. (2013)“Paradigma Pembangunan Pertanian: Pertanian Berkelanjutan Berbasis Petani Dalam Perspektif Sosiologis.” Jurnal Sosiologi Universitas Syiah Kuala 3, no. 3.

Moleong, Lexy J. (1983) Metode Penelitian Kualitatif. Bandung: Remaja Rosdakarya.

Prabowo, Rossi. (2010) “Kebijakan Pemerintah Dalam Mewujudkan Ketahanan Pangan Di Indonesia." Mediagro 6, no. 2.

Rivai, Rudy S, and Iwan. S Anugrah (2011). "Konsep Dan Implementasi Pembangunan Pertanian Berkelanjutan Di Indonesia." Forum Penelitian Agro Ekonomi 29, no. 1.

Suryana, Ahmad (2014). "Menuju Ketahanan Pangan Indonesia Berkelanjutan 2025: Tantangan Dan Penanganannya." Forum Penelitian Agro Ekonomi 32, no. 2.

Wibowo, Willy. (2020) "Hubungan Peneliti Dan Analis Kebijakan Dalam Pembuatan Rekomendasi Kebijakan Pada Badan Penelitian Dan Pengembangan Hukum Dan HAM.” Jurnal Ilmiah Kebijakan Hukum 14, no. 1

Wulandari, Dian Ayu, and Amni Zarkasyi Rahman (2017). "Implementasi Kebijakan 
Perlindungan Lahan Pertanian Pangan Berkelanjutan (LP2B) Di Kabupaten Tegal (Studi Implementasi Peraturan Daerah Kabupaten Tegal Nomor 10 Tahun 2012 Tentang Rencana Tata Ruang Wilayah Kabupaten Tegal Tahun 2012-2032)." Journal of Public and Management Review 6, no. 2. 